\title{
Gender-based differences in fear of crime in public spaces: An investigation of a safe district in Istanbul
}

Safety is an important issue in large cities. Fear of crime, on the other hand, is an issue independent of actual crime rates, but it is directly related to spatial qualities, affecting people's feelings of safety. Fear of crime also varies by gender. This study investigates fear of crime in public places in a particularly safe location of a large metropolis. In this context, it focuses on the effects of spatial characteristics on fear of crime and the differences between genders. The study was carried out in one of the safest districts of Istanbul, which women consider safe. In a 2017 survey,
387 male and female participants of varying ages were questioned regarding their fear, when they experienced such fear, and their reasons for fear in public space. According to the results, women felt a certain amount of fear of crime even in a safe district of the city. In addition, gender-based differences concerning fear in public places and the conditions in which fear is felt are significant.

Keywords: fear of crime, risk assessment, public space, gender, Istanbul 


\section{Introduction}

This study examines gender differences in public spaces as a factor in fear of crime. One important reason why women avoid public spaces is fear of crime. This affects the gender balance in public spaces. It is therefore important for women to feel safe in public spaces to preserve their presence in these areas. In this context, the study's main goal is to determine gender-based differences in the perception of safety and the source of fear of crime. The findings of this research may inform new regulations or amendments to current legislation.

One of the main motives for this study is the alarming increase in violence against women in Turkey in the last decade. Femicide rates, which are one of the most striking consequences of this violence, increased by 30.6\% between 2016 and 2018 ( $428.9 \%$ in 15 years; Tığlı, 2019). Official records and data on crimes against women are not shared with the public in Turkey, and therefore it was not possible to include data relating to crimes other than murder in this study. Moreover, according to Lordoğlu (2018), reporting sexual assault and sexual harassment to the police is rather low in Turkey, and the definition and boundaries of sexual harassment are very blurred in Turkish society, and so this must be taken into account when assessing crimes against women. The report on violence against women in Turkey (Karal \& Aydemir, 2012) emphasizes that, rather than the crime rates of a particular place, the rate of violence against women throughout the country may be a more significant factor influencing women's fear of crime. Male violence is an extension of the patriarchal belief that a woman's place is in the home; this manner of thinking implies that violence is overlooked and legitimized, especially when state intervention is insufficient. This results in women feeling defenceless and vulnerable. Even though women may not actually be victimized, it prevents them from utilizing the city's public spaces freely. News about women in Istanbul being attacked in public by men because of their clothing, and assailants not receiving the expected criminal penalties, are causing women to experience increasing fear in public spaces. Therefore, this study investigates gender-based differences in fear of crime in public spaces. In particular, it examines aspects related to fear of crime in public space and it seeks to determine how problems can be solved by urban design.

\subsection{Literature review}

Fear of crime stems from the belief of being victimized by crime. It is an emotional reaction caused by fear, danger, and anxiety toward potential violent crimes (Covington \& Taylor, 1991). When it occurs, it is combined with a feeling of vulnera- bility due to the threat of physical harm (Garofalo, 1981; Ward et al., 1990). This is also described as a sense of insecurity. It can also be defined as an emotional reaction characterized by a sense of danger or anxiety created by crime or symbols related to crime (Ferraro \& LaGrange, 1987). Individuals that fear crime avoid certain routes (Ravenscroft et al., 2002), walk less (Ross, 1993; Foster et al., 2010), interact less socially (Ross \& Jang, 2000), and change their habits (Garofalo, 1981). When an individual's perception of victimization is higher than the objective probability, fear of crime can turn into a serious problem. Fear of crime is both a personal and social problem that reduces the quality of life because it restricts access to social and cultural activities. It has a detrimental effect on individuals' interaction in society (Sacco, 1993). The complex structure of fear of crime means that it is becoming a social and political problem more comprehensive than crime itself (Garofalo, 1981; Ferraro \& LaGrange, 1992).

Fear of crime is an increasing fear type, especially for the residents of larger cities, and it is significantly related to how individuals perceive their surroundings, and how they evaluate themselves in their surroundings (Ferraro, 1995; Çardak, 2012). Consequently, fear of crime is a factual and perceptual problem. Crime or fear of crime is directly related to education level, income level, age, ethnicity, place of residence, sense of belonging to a space, and gender (Gray et al., 2011). A main approach to fear of crime based on an individual's characteristics is the vulnerability perspective approach. According to this approach, groups that are deemed weaker, more defenceless, more unprotected, and more vulnerable to external factors in terms of physical, socioeconomic, and cultural status are assumed to feel fear of crime more often than other groups in society (Ferraro, 1995; Çardak, 2012; Kul, 2013). Women, the elderly, the handicapped, and individuals without social support interpret the information they receive from their surroundings as a more intense fear of crime (Covington \& Taylor, 1991; Çardak, 2012).

More vulnerable or disadvantaged groups of society with regard to security (i.e., women, migrants, the poor, LGBT individuals, handicapped people, the elderly, children, and the homeless) are mostly examined in studies on fear of crime (Covington \& Taylor, 1991; Pain, 2001; Otis, 2007; Jackson, 2009). Although some studies have not shown significant differences based on age, they almost always conclude that fear of crime is higher in women than men (Valentine, 1989; MacMillan et al., 2000; Pain, 2001; Jackson, 2009; Uludağ, 2010; Kul, 2013; Öztürk et al., 2016). Jackson's (2009) study showed a gender difference disfavouring women in crimes against persons, whereas a gender difference was not detected in crimes against property. 
Even though crime and fear of crime are related to each other as concepts, the relationship between them is weak (Jackson, 2009; Dolu et al., 2010). It is also important not to ignore the influence of mass media and the environment in fear of crime. The traditional view of society about women should also be considered in women's fear of crime, which is detailed below. Finally, even though fear of crime is related to crime itself, it emerges as an independent factor after a certain point. This explains why fear of crime is seen not only in residents of districts with high crime rates, but also in residents of safer cities or districts where crime rates are lower (Furstenberg, 1971; Ferraro, 1995).

\subsubsection{Fear of crime and gender}

Women are undoubtedly the most vulnerable part of society when it comes to fear of crime. The fear geography of women in the Western world has been studied since the late twentieth century (Valentine, 1989; Treske, 1990; Pain, 1991; Koskela, 1997). On the other hand, in Turkey fear studies focusing on women have been gaining prominence only in the last decade (Dolu, 2010; Çardak, 2012; Erkan, 2015; Yirmibeşoğlu \& Ergun, 2015). The vulnerability perspective is an approach that explains the gender difference in fear of crime. According to the vulnerability perspective, personal vulnerability perception is an important factor affecting fear of crime in individuals (Taylor \& Hale, 1986; Franklin et al., 2008). Individuals that feel physically, socially, and economically defenceless experience a heightened sense of fear of crime (Covington \& Taylor, 1991; Hale, 1993) because they perceive themselves to be too weak and vulnerable to stand up against potential criminals and they see themselves as the potential victims of many crimes. This implies that women and the elderly are physically more vulnerable compared to men and youth. Hence, women (Warr, 1984; Hale, 1993; Mirrlees-Black et al., 1996; Sandberg \& Rönnblom, 2013) and the elderly (Warr, 1984; Ferraro \& LaGrange, 1992; Jackson, 2009) report a higher level of fear of crime. When recorded victimizations are compared, women, especially older women, experience fear of crime more even though they are rarely the victims; however, young men experience fear of crime less, even though their actual victimization potential is higher (Hale, 1993). This inconsistency between fear levels and actual victimization rates is called the gender-fear paradox.

Studies of gender-based differences, including this study, show that women living in urban areas experience fear of crime more often and more intensely compared to men living in the same areas (Valentine, 1989, 1992; Hale, 1993; Koskela, 1999; Pain, 1991, 2001; Dolu et al., 2010; Sandberg \& Rönnblom, 2013; Uçan et al., 2016). Data on fear of crime show that there are relatively small but statistically meaningful differences between fear rates expressed by men and women (Gilchrist et al., 1998). As a result, gender surfaces as an important indicator of fear of crime.

Fear of crime affects women in two ways. Women may either stay away from certain places and activities to avoid the sense of fear, or they may internalize the prejudices and ideologies that harm women in general (Koskela, 1997; Sutton et al., 2011). Either way, fear of crime is a mechanism that forces women out of particular urban spaces and social relationships. Consequently, women usually adopt avoidance behaviour because of fear of crime, and they place restrictions on their own lives. These restrictions may have to do with when they leave and return to their homes, where they go, how they dress, who they communicate with, and how they communicate. If the fear is too high, their lives are completely restricted by these influences (Valentine, 1989; Pain, 1991; Koskela, 1999; Çardak, 2012; Sandberg \& Rönnblom, 2013; Tandoğan \& Şimşek İlhan, 2016). Fear of crime especially restricts women's access to public spaces and influences their behaviour in public. Because women avoid public spaces, the gender balance in public spaces deteriorates, further increasing women's fear of using these spaces.

\subsubsection{External factors in fear of crime}

It would be wrong to think that fear of crime stems only from an individual's personal perception. Therefore, many studies focus on external factors such as physical space itself, or mass media creating the perception of fear. A person's fear of crime is not parallel to crime levels but is instead related to the news about crime in the mass media (Kohm et.al., 2002; Smolej \& Janne, 2006; Çardak, 2012; Sandberg \& Rönnblom, 2013; Callanan \& Rosenberger, 2015; Sallan Gül \& Altındal, 2015). Fear stimulates people to take precautions. In this case, even if there is not an actual danger, news about assault, rape, and violence against women in the mass media influences how women conduct themselves in public spaces. A study in Turkey about women's fear of crime showed that half of women experience greater fear of crime in public spaces if they are wearing revealing clothing or if they are alone (Tandoğan \& Şimşek İlhan, 2016). Since mass media recently began broadcasting news about physical assaults on women dressed in revealing clothing, increasingly more Turkish women have experienced fear of crime (Internet 1, Internet 2).

External factors affecting fear of crime are not limited to the mass media. According to another approach, irregularities in the built environment can be interpreted as clues of insecurity and are effective in creating fear of crime. Dark, deserted areas where trash is not collected, places where there are vandalized structures, or places characterized by an imbalance of men 


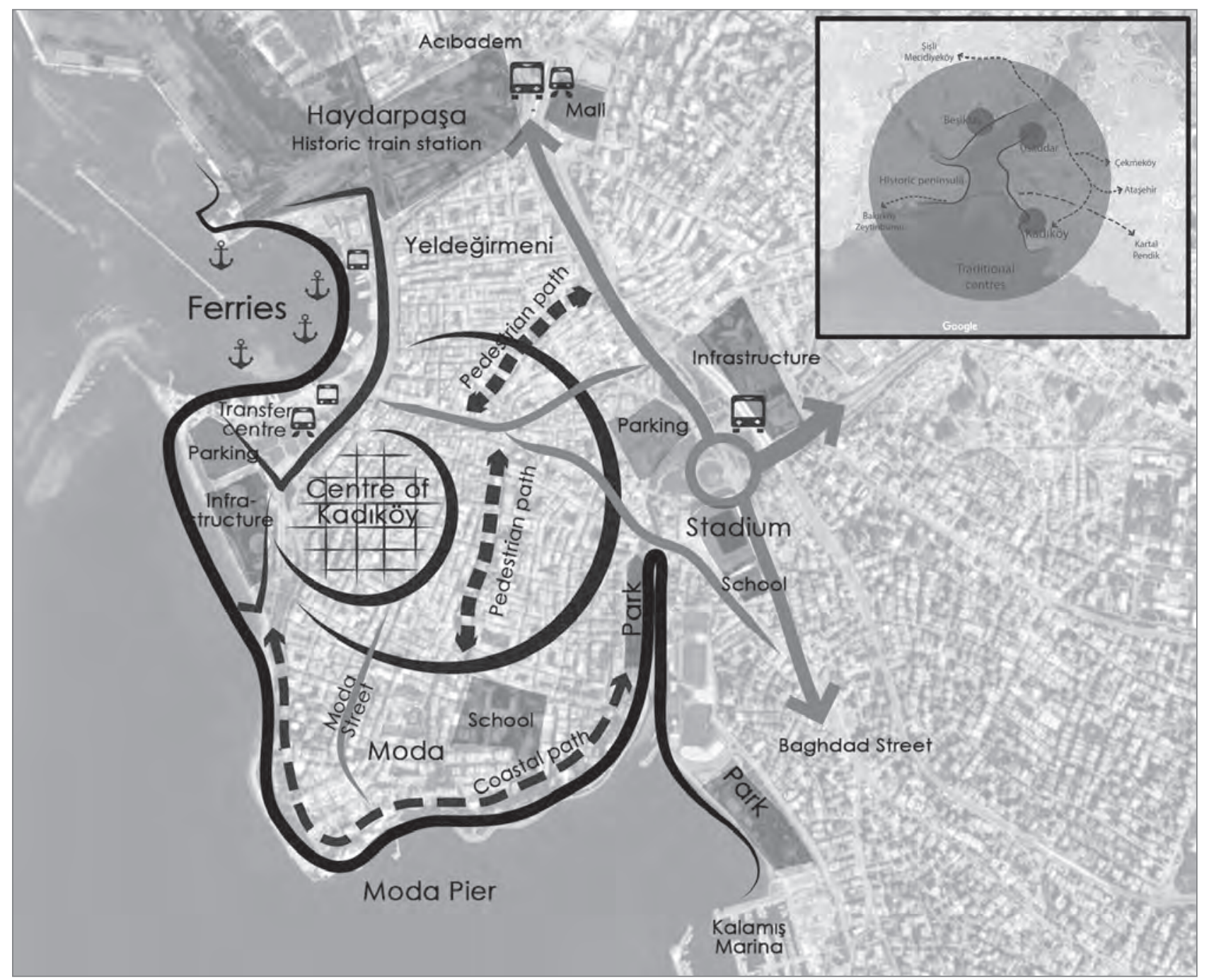

Figure 1: Location of and facilities in Kadıköy (illustration: G. E. Albayrak).

and women cause individuals to fear being victimized (Vrij \& Winkel, 1991; Nasar \& Fisher, 1993; Newman, 1996; Kalpana \& Ashish, 2015). Deserted alleys, dark passages, insufficient lighting, isolated urban spaces, and late-night public transport are usually described as conditions or spaces where fear of crime is experienced the most (Treske, 1990; Warr, 1990; Greene, 2003; Erkan 2015; Tandoğan \& Şimşek İlhan, 2016). According to Tandoğan and Şimşek İlhan (2016) and Treske (1990), women experience fear of crime more in deserted areas or when it is dark. In contrast, a study performed in Helsinki showed that women thought of winter and summer nights as equally dangerous despite the difference in the level of light. Their explanation is that, even though winter nights are darker, there are more men in public spaces on summer nights because of favourable weather (Koskela, 1998). According to this, the fear most women experience does not stem from spatial features, but from fear of men (Valentine, 1989). This shows that women's fear of crime cannot be removed by simply rectifying the space (Koskela \& Pain, 2000). As a result, women experience fear of crime more than men, and this seems to be a contributing factor in limiting their participation in public life.

\section{Method}

\subsection{Study area}

Kadıköy is a district on the Asian side of Istanbul (Figure 1). Kadıköy was selected for this study because, even though it has a crowded and diversified user profile, it is considered a safe area of Istanbul, especially by women (Bilen et al., 2013; Lordoğlu, 2018). This is important because it helps focus on fear of crime independently from actual crime rates. A study by Lordoğlu (2018) of single women also showed that Kadıköy was regarded as the most comfortable district to live in as a woman in Istanbul. 

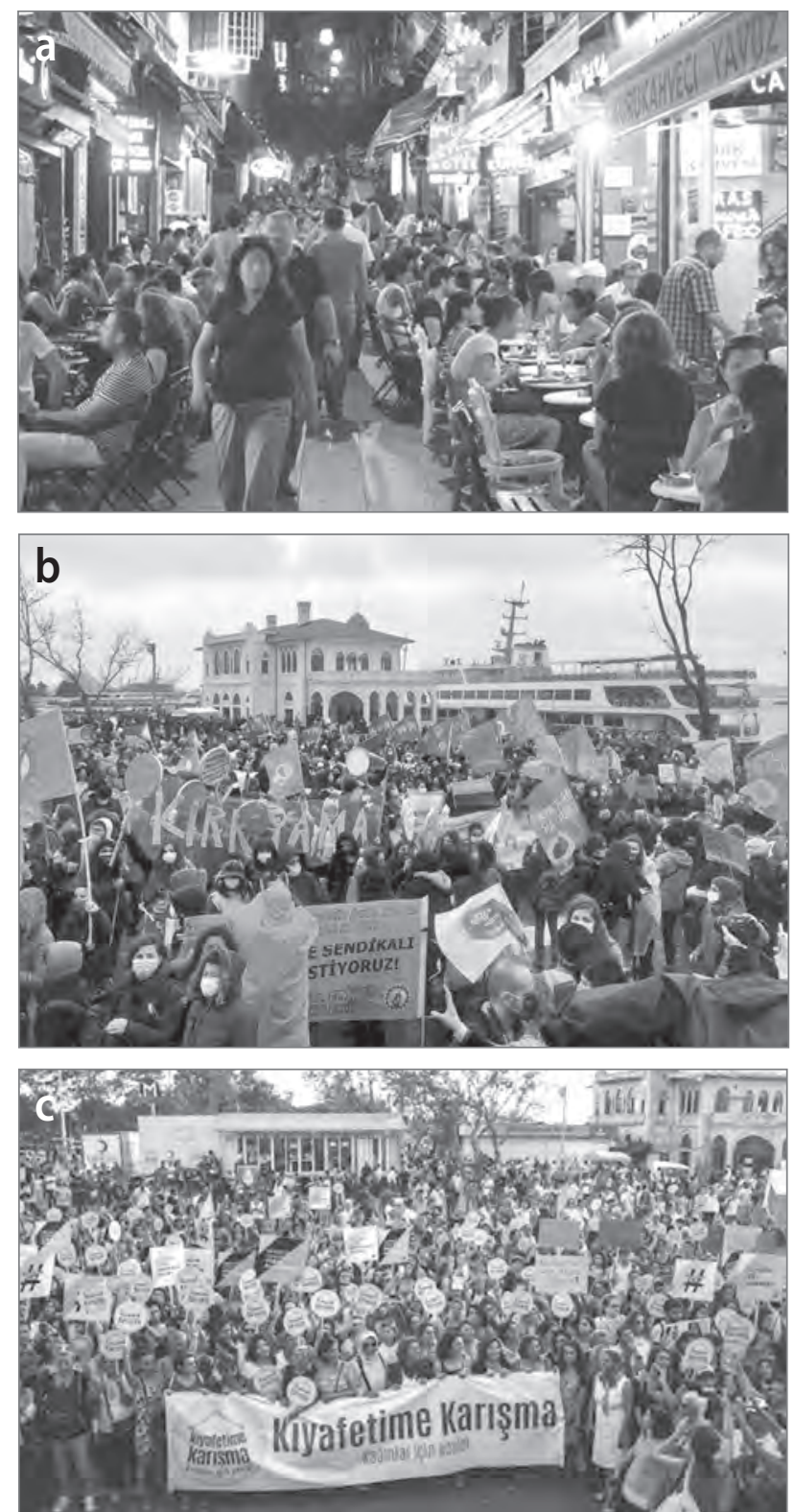

Figure 2: a) Nightlife (photo: Internet 3); b) Women's Day celebration (photo: Internet 4); c) "Do not interfere with my clothes" demonstration in Kadıköy (photo: Internet 5).

As a result of media coverage of women that were attacked because of their clothing, protests were held in several parts of Istanbul in July 2017, including Kadıköy. These organized protests showed the impact of fear of crime in public spaces. One reason why this study was carried out in Kadiköy is the "do not interfere with my clothes" demonstration. Due to the density of both formal and informal social movements, Kadıköy is a district that differs significantly from the rest of Istanbul in aspects such as socioeconomic variables, culture, and nightlife (Figure 2).

The district was defined as a cultural and transfer hub in the metropolitan master plan, and it has become more crowded
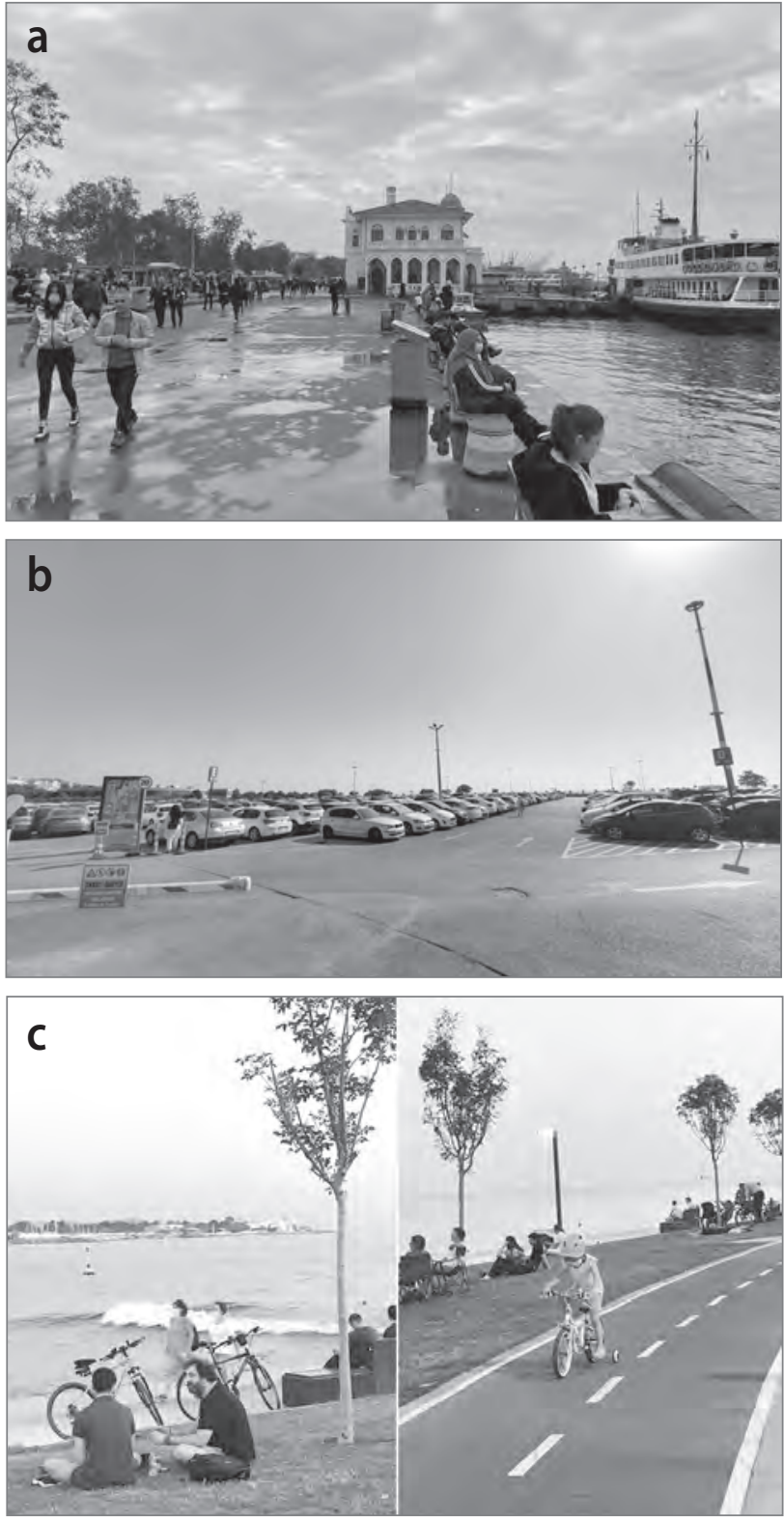

Figure 3: Waterfront functions in Kadıköy; a) piers (photo: N. Ç. Erkan); b) parking space (photo: B. Sevin); c) recreation area (photo: F. Çobanoğlu).

and more cosmopolitan in recent years. Due to the impact of entertainment, food, and beverage venues, cultural activities have gathered pace in Kadıköy. Because of the corresponding availability of public transportation (ferry, bus, metro, etc.), Kadıköy has gained a large visitor population and has become a crowded area that is lively until late at night. According to 2017 data from TÜIK (the Turkish Statistical Institute), the population of the Kadiköy district is 451,453 and the district has a daily visitor capacity of more than six times its population (Kadıköy District Registry Office, 2017). Kadıköy was chosen as a study area to cover the traditional market (with the highest visitor population), retail trade areas, entertainment venues, the waterfront centre, which is regarded as a transfer 

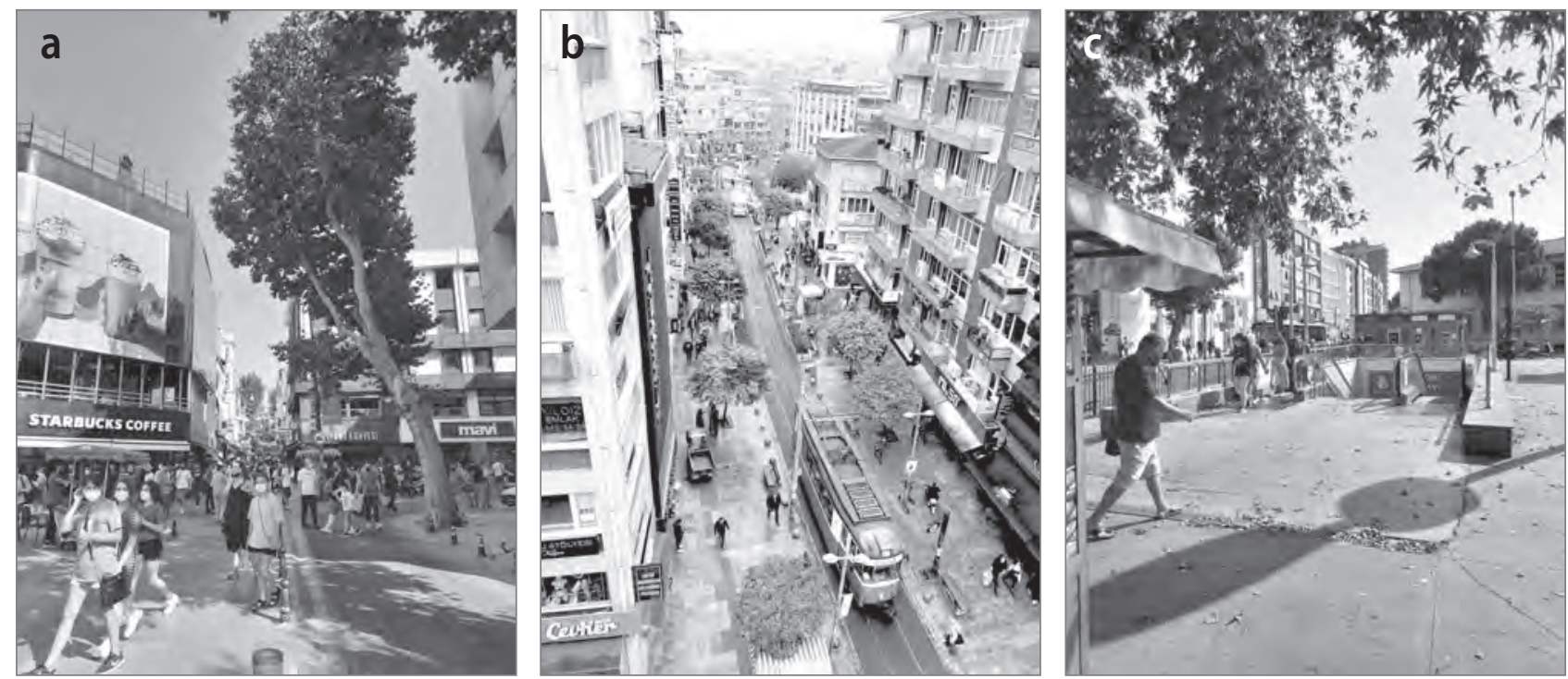

Figure 4: a) People in the commercial area (photo: B. Sevin); b) car-free shopping street (photo: N. Ç. Erkan); c) metro station (photo: B. Sevin).

centre as well as a recreation area, and the other transportation transfer centre on land (Figures 3,4). This area was observed on different days and at different times, and a survey was carried out using the methodology explained below.

\subsection{Survey}

This study focuses on fear of crime among users of a safe public space and the differences between men and women in the vulnerable group in this regard. It questions the types of locations where fear is felt and the conditions that may create fear. Based on this, the research questions are: 1) In a safe district, is there a difference in fear of crime felt by different genders? 2) Does the quality of a public space and its conditions have an effect on fear of crime? and 3) Are there gender-based differences in the sense of fear in the public space studied, taking into account its quality and conditions? Based on these questions and the study's starting point, the hypothesis of the study is that women feel more fear of crime in public spaces compared to men, independent of the safety of the district.

In light of information about fear of crime and the study area, an in-depth survey was conducted to collect the experiences and thoughts of the place users in the study area. The survey inquired about the following: a) personal information of users such as gender, age, and education level, in addition to the reasons why they were in Kadıköy or how often they visited; b) whether they felt safe in Kadiköy and the locations where they experienced fear in Kadıköy, and c) the locations and conditions that might be a source of fear. In this third set of questions, fifteen locations and nine conditions were defined as a source of concern. Participants were asked to evaluate these locations and conditions on a five-point Likert scale. The values were completely disagree (1), disagree (2), indecisive (3), agree
(4), and completely agree (5). The participants were free to mark as many options as they desired.

These locations and conditions were selected from a group of places that cause fear, identified in a 2014 pilot study with the participation of sixty women. These locations were mainly dark and deserted places where seeing and being seen are problems, and crowded places where a criminal can remain anonymous. Alleys and main streets were also included in the survey, but they are less significant and more neutral in fear of crime. The locations selected for evaluation in the study are described by their functions and features without actually naming various neighbourhoods in the study area. The goal here is not to directly label the locations, but to understand what these locations represent for the users. A statistically meaningful difference was expected to be found between these locations. Situations that may occur in any place, independent of location, were also listed in the questionnaire under the heading "conditions". These conditions are being lost, a crowd, deserted areas, darkness, verbal abuse by a stranger, the presence of stray animals, the presence of beggars, drug users, and so on, a crowd staring at you, and a crowd making noise. In this context, gender-based fear of crime was a dependent variable, and public locations with certain qualities and certain conditions were independent variables.

The survey was carried out in May and June 2017 and was collected from 387 respondents, 170 online and 217 in person. The validity of the data obtained before the statistical analyses for normal distribution was checked by an analysis of skewness and kurtosis values. Because these were in a range of \pm 2 , it was decided that the data had a normal distribution (George \& Mallery, 2010). In addition, because the data were collected via both face-to-face and web-based methods, whether the groups 
Table 1: Respondents' gender and education levels, and their reasons for being in Kadıköy.

\begin{tabular}{|c|c|c|c|c|}
\hline Criterion and value & & Female: $n(\%)$ & Male: $n(\%)$ & Total: $n(\%)$ \\
\hline \multirow{7}{*}{ Age } & $15-25$ & $63(27)$ & $35(23)$ & $98(25)$ \\
\hline & $26-35$ & $91(38)$ & $62(41)$ & $153(40)$ \\
\hline & $36-45$ & $51(22)$ & $24(16)$ & 75 (19) \\
\hline & $46-55$ & $17(79)$ & $11(7)$ & $28(7)$ \\
\hline & $56-65$ & $9(6)$ & $13(9)$ & $22(6)$ \\
\hline & $65+$ & $6(14)$ & $5(24)$ & $11(17)$ \\
\hline & Total & $237(100)$ & $150(100)$ & $387(100)$ \\
\hline \multirow{6}{*}{ Education } & Primary school & $7(3)$ & $6(4)$ & $13(3)$ \\
\hline & Secondary vocational school & $5(2)$ & $7(5)$ & $12(3)$ \\
\hline & High school & $38(16)$ & $20(13)$ & $58(15)$ \\
\hline & Bachelor's & $143(60)$ & $96(64)$ & $239(62)$ \\
\hline & Master's, PhD & $44(19)$ & $21(14)$ & $65(17)$ \\
\hline & Total & $237(100)$ & $150(100)$ & $387(100)$ \\
\hline \multirow{3}{*}{ Reason in Kadıköy } & Living and working & $65(27)$ & $55(37)$ & $120(31)$ \\
\hline & Other & $172(73)$ & $95(63)$ & $267(69)$ \\
\hline & Total & $237(100)$ & $150(100)$ & $387(100)$ \\
\hline Total & & $237(61.2)$ & $150(38.8)$ & $387(100)$ \\
\hline
\end{tabular}

Table 2: Gender-based chi-squared analysis for "place feels unsafe".

\begin{tabular}{|c|c|c|c|c|c|c|c|}
\hline & & \multicolumn{2}{|c|}{ Gender } & \multirow[t]{2}{*}{ Total } & \multirow[t]{2}{*}{$x^{2}$} & \multirow[t]{2}{*}{$S D$} & \multirow[t]{2}{*}{$p$} \\
\hline & & Female & Male & & & & \\
\hline $\begin{array}{l}\text { Is there any place in Kadıköy where you do not } \\
\text { feel safe? }\end{array}$ & No & 123 & 101 & 224 & 8.976 & 1 & .003 \\
\hline & Yes & 114 & 49 & 163 & & & \\
\hline Total & & 237 & 150 & 387 & & & \\
\hline
\end{tabular}

Table 3: Correlation between feared spaces and gender.

\begin{tabular}{lll}
\hline Locations & $r$ & $p$ \\
\hline Public transportation & $-.209^{* *}$ & .000 \\
\hline Bus or minibus stops & $-.181^{* *}$ & .000 \\
\hline Metro stations & $-.188^{* *}$ & .000 \\
\hline Underpasses & $-.232^{* *}$ & .000 \\
\hline Residential areas & $-.278^{* *}$ & .000 \\
\hline Market area at night & $-.175^{* *}$ & .001 \\
\hline Waterfront at night & $-.280^{* *}$ & .000 \\
\hline Park & $-.215^{* *}$ & .000 \\
\hline Parking space & $-.288^{* *}$ & .000 \\
\hline Indoor parking space & $-.395^{* *}$ & .000 \\
\hline Locations with graffiti & $-.115^{*}$ & .023 \\
\hline Alleys & $-.177^{* *}$ & .000 \\
\hline Main streets & $-.200^{* *}$ & .000 \\
\hline Near venues with alcohol & $-.273^{* *}$ & .000 \\
\hline Near deserted and empty areas & $-.175^{* *}$ & .001 \\
\hline
\end{tabular}

Note: $P$ value of analysis shows it's statistical significance. Both $p<0.05$ and $p<0.01$ are considered statistically significant while a figure that is less than 0.01 is viewed as highly statistically significant (Greenland, et al., 2016).

${ }^{*} p<0.05,{ }^{* *} p<0.01$. showed a similar distribution was checked with the Wald-Wolfowitz runs test, and it was concluded that the groups showed a similar distribution. Online surveys were applied to include users that could not spare time for an in-person survey on the street, for younger generations that are comfortable using social media, and for individuals that avoid communication with strangers due to fear of crime. Online surveys were delivered via social media to individuals connected with the Kadıköy district in some way (who live in, work in, or visit Kadıköy). The in-person surveys were conducted by interns. A non-probability convenience sampling method was used, and the surveys were carried out with random users during weekdays and weekends at public spaces in Kadıköy. The number of women $(n=237)$ that participated in the survey is higher than the number of men $(n=150)$. The reason for this is that women are more willing to participate in surveys than men, and/or because men are more hesitant to express their fears (Crawford et al., 1990; Jackson, 2009: 371, 381).

Table 1 shows that $79 \%$ of the respondents have an undergraduate or higher degree. Thus, the neighbourhood residents or 
Table 4: Regression of feared spaces by gender.

\begin{tabular}{llllll}
\hline Dependent variable & Adj. $R^{2}$ & $F($ sig.) & $\beta$ & $t($ sig. $)$ & Effect size \\
\hline Public transportation & .041 & $17.551(.000)$ & -.209 & $-4.189(.000)$ & Small \\
\hline Bus-minibus stops & .030 & $12.977(.000)$ & -.181 & $-3.602(.000)$ & Small \\
\hline Metro stations & .033 & $20.499(.000)$ & -.188 & $-3.755(.000)$ & Small \\
\hline Underpasses & .072 & $31.039(.000)$ & -.273 & $-5.571(.000)$ & Small \\
\hline Residential areas & .028 & $12.134(.001)$ & -.175 & $-3.483(.001)$ & Small \\
\hline Market area at night & .037 & $15.984(.000)$ & -.200 & $-3.998(.000)$ & Small \\
\hline Waterfront at night & .051 & $21.807(.000)$ & -.232 & $-4.670(.000)$ & Small \\
\hline Alleys & .075 & $32.264(.000)$ & -.278 & $-5.680(.000)$ & Small \\
\hline Main streets & .028 & $12.097(.001)$ & -.175 & $-3.478(.001)$ & Small \\
\hline Park & .076 & $32.859(.000)$ & -.280 & $-5.732(.000)$ & Small \\
\hline Near venues with alcohol & .044 & $18.610(.000)$ & -.215 & $-4.314(.000)$ & Small \\
\hline Parking space & .081 & $34.862(.000)$ & -.288 & $-5.904(.000)$ & Small \\
\hline Indoor parking space & .154 & $71.313(.000)$ & -.395 & $-8.445(.000)$ & Medium \\
\hline Locations with graffiti & .011 & $5.197(.023)$ & -.115 & $-2.280(.023)$ & Small \\
\hline Near deserted and empty areas & .029 & $12.404(.000)$ & -.177 & $-3.522(.000)$ & Small \\
\hline
\end{tabular}

visitors have high levels of education; individuals with a higher level of education were more willing to take the survey than those without. Thirty-one per cent of the respondents lived or worked in Kadıköy, and $69 \%$ of the respondents were visitors to Kadıköy for various reasons (Table 1).

\section{Results}

The study investigated whether women and men feel safe in Kadıköy. A chi-squared test was conducted to determine whether the sense of security is dependent on gender, and the dependency between the variables was found to be statistically significant $\left(\chi^{2}=8.97 ; p<.05\right.$; Table 2$)$.

When calculating the correlation between the locations where fear is felt and gender, all the results are negative and statistically significant $(p<0.05$; Table 3$)$.

Dummy coding was performed to subject the gender variable to regression analysis: female $=0$, male $=1$. Therefore, being a man has a negative effect and men score lower on these questions. In the regression analysis, it was observed that the independent variable "gender" explained all the variables related to spaces in a meaningful way. Among these, the greatest effect was determined for the variable "indoor parking space" $\left(R^{2}=.154, F(1,385)=71.31, p<.001\right)$. The variable "gender" provides a significant estimation of the variable "indoor parking space" $(\beta=-.395, t(385)=-8.445, p<.001$; Table 4$)$.

In the correlation analysis, the correlation between gender and "crowd", "presence of stray animals", and "crowd making noise" was not statistically significant $(p>0.05)$. For this reason, these variables were not included in the regression analysis (Table 5).
Table 5: Correlation between feared conditions and gender.

\begin{tabular}{lll}
\hline Conditions & $r$ & $p$ \\
\hline Being lost & $-.206^{* *}$ & .000 \\
\hline Crowd & -.070 & .167 \\
\hline Deserted areas & $-.348^{* *}$ & .000 \\
\hline Darkness & $-.416^{* *}$ & .000 \\
\hline Beggars, addicts, etc. & $-.253^{* *}$ & .000 \\
\hline Verbal abuse by stranger & $-.427^{* *}$ & .000 \\
\hline Presence of stray animals & -.094 & .064 \\
\hline Crowd staring at you & $-.279^{* *}$ & .000 \\
\hline Crowd making noise & -.091 & .073 \\
\hline
\end{tabular}

Note: ${ }^{*} p<0.05,{ }^{* *} p<0.01$.

In the regression analysis, dummy coding was used to understand the effect of being male. For this reason, the data were recoded as female $=0$ and male $=1$. The results of the regression analysis showed that being male had a negative effect (Table 6). This shows that women have higher scores on these conditions, whereas men scored less. In this analysis, the independent variable "gender" explained all the variables in a meaningful way. However, the effect size of the variables "deserted areas" $\left(R^{2}\right.$ $=.040, F(1,385)=17.07, p<.001)$, "darkness" $\left(R^{2}=.171\right.$, $F(1,385)=80.73, p<.001)$, and "verbal abuse" $\left(R^{2}=.181\right.$, $F(1,385)=86.08, p<.001)$ are higher than other variables. Regression analysis was not performed because there is no significant correlation between the presence of stray animals, a crowd making noise, and crowds.

In the analyses conducted, the variable "gender" has a negative and statistically significant correlation with each location and condition. Being a man has a negative effect in these conditions and reduces fear scores. However, the variable "gender" has the 
Table 6: Regression of feared conditions by gender.

\begin{tabular}{llllll}
\hline Dependent variable & Adj. $R^{2}$ & $F($ sig.) & $\beta$ & $t$ (sig.) & Effect size \\
\hline Being lost & .040 & $17.071(.000)$ & -.206 & $-4.132(.000)$ & Small \\
\hline Deserted areas & .119 & $52.919(.000)$ & -.348 & $-7.275(.000)$ & Small to medium \\
\hline Darkness & .171 & $80.736(.000)$ & -.416 & $-8.985(.000)$ & Medium \\
\hline Beggars, addicts, etc. & .061 & $26.258(.000)$ & -.253 & $-5.124(.000)$ & Small \\
\hline Verbal abuse by stranger & .181 & $86.084(.000)$ & -.427 & $-9.278(.000)$ & Medium \\
\hline Crowd staring at you & .076 & $32.566(.000)$ & -.279 & $-5.707(.000)$ & Small \\
\hline
\end{tabular}

highest explanatory correlation with the variable "verbal abuse by stranger". In other words, women are frightened by "verbal abuse by stranger" more than by other conditions.

\section{Discussion}

This study investigated the relationship between gender and locations and conditions that cause fear of crime in public spaces. The results show that, even though a public space is known to be safe, women feel more fear than men under any circumstance. According to a study conducted in Istanbul, the percentage of people that think they cannot act freely and safely due to fear of being victimized was 79\% (Kul, 2013: 86; Karasu, 2017: 63). However, the results of this study show that the percentage of people that feel unsafe in certain districts of Kadıköy is $42.1 \%$. According to these data, Kadiköy is safer compared to the entire Istanbul metropolitan area. On the other hand, $70 \%$ of the participants that felt unsafe in Kadıköy are women. This result shows that women experience the feeling of insecurity more than men. According to the results of a 2016 TÜIKK report on life satisfaction, the percentage of people feeling in danger while walking alone at night in the districts where they live was $26.2 \%$; this percentage was $15.2 \%$ among men and $37 \%$ among women. The percentage of people feeling safe in the area they lived was $71 \%$ among men and $47.5 \%$ among women. From these data, it can also be seen that women experience a feeling of insecurity more than men. In other words, this study found that there is a significant correlation between gender and sense of security, and that women have a higher rate of feeling unsafe.

One question the study sought to answer was the effect that the qualities and conditions of public spaces had on fear of crime. It was shown that qualities and conditions such as desolation and darkness have an effect on fear of crime. One outstanding issue in the study is a contradiction regarding the results obtained for deserted areas. Although no difference was found between men and women regarding fear felt in deserted areas, it was observed that the factor "deserted areas" had an effect varying from small to medium in the regression analysis. However, the analysis showed a $p$ value of 0.073 for the variable "deserted areas", which indicates that the correlation is partially significant. If more participants had been included in the study, this value may have reached a statistically significant level (Pritschet et al., 2016). As a result, it is observed that locations such as indoor parking spaces and desolate areas cause fear, and women are more affected than men by conditions such as darkness, where visibility is problematic, and by verbal abuse. In a study conducted among women in Istanbul, it was found that women are most fearful of physical harassment (42\%) and dark streets (11.4\%). They also fear being assaulted (9.24\%) in public places (Erkan, 2015). In a study by Tandoğan and Şimşek İlhan (2016) investigating fear of crime among female city dwellers, $88.0 \%$ of women were afraid in deserted/quiet streets and roads at night. These results are also consistent with the results obtained in this study.

It has been concluded that fears such as gender-based verbal abuse are more prominent among fears that shape female behaviour in public spaces. Research by Tandoğan and Şimşek Illhan (2016) reveals that verbal abuse by a stranger (63.4\%) is a very common situation in Istanbul. In the interviews conducted in this study, some young female university students stated that they wear headphones when they are alone in order not to hear verbal abuse or to pretend not to hear it. Sometimes gazes in public spaces can be as offensive as verbal abuse, and they restrict women's behaviour. Because the boundaries of harassment applied to women in a male-dominated society cannot be defined very clearly (although "looking" and "verbal abuse" can be taken for granted by women in some cases), such behaviours nevertheless continue to be a source of fear.

\section{Conclusion}

Although women are safer and feel free in Kadıköy compared to other districts of Istanbul, it has been determined that they still have a fear of crime. As seen in similar studies about fear of crime, gender is an important factor affecting fear of crime in public spaces. Urban planning and urban design regulations can produce solutions to overcome fear of crime, which is a feature of urban spaces. However, research shows that regulating urban spaces is not enough. The study confirmed that some 
social precautions should be taken, especially in preventing fear of crime among women.

It should be noted that the research discussed in this article has certain limitations. The high level of education of individuals that voluntarily participated in the research does not reflect the general situation of Istanbul. Therefore, the results of this study cannot be generalized for Istanbul. The next step of the study will be to compare fear of crime in a safe district with an unsafe district and to investigate the gender differences in fear of crime felt in these areas.

Nilgün Çolpan Erkan

Yıldız Technical University, Faculty of Architecture, Department of Urban and Regional Planning, Istanbul, Turkey

E-mail: nilgunerkan@gmail.com

Beril Sevin Topçu

Municipality of Kadıköy, Istanbul, Turkey

E-mail: berilsevin@gmail.com

\section{Acknowledgment}

The authors of this study thank Kağan Güney for his support in the statistical calculations for the study, and Meryem Çağış and Ebru Çakmak for their assistance in conducting the survey in the field.

\section{References}

Bilen, Ö., Aşkın, Ö. E., Büyüklü, A. H., Ökten, A. \& Mehmet, G. Ü. R. (2013) How the fear of crime spatially differs among the districts of Istanbul? Social Sciences, 8(4), pp. 153-164.

DOI: 10.12739/NWSA.2013.8.4.3C0115

Callanan, V. \& Rosenberger, J. S. (2015) Media, gender, and fear of crime. Criminal Justice Review, 40(3), pp. 322-339. DOI: 10.1177/0734016815573308

Çardak, B. (2012) Kadınların Suç Korkuları Üzerine Nitel Bir Çalıșma. Güvenlik Bilimleri Dergisi, 1(1), pp. 23-45. DOI: 10.28956/gbd.239715

Covington, J. \& Taylor, R. (1991) Fear of crime in urban residential neighborhoods: Implications of between- and within-neighborhood sources for current models. The Sociological Quarterly, 32(2), pp. 231249. DOI: 10.1111/j.1533-8525.1991.tb00355.x

Crawford, A., Jones, T., Woodhouse, T. \& Young, J. (1990) The second Islington crime survey. London, Centre for Criminology, Middlesex Polytechnic.

Dolu, O., Uludağ, Ş. \& Doğutaş, C. (2010) Suç Korkusu: Nedenleri, Sonuçları ve Güvenlik Politikaları Ilişskisi. Ankara Üniversitesi SBF Dergisi. 65(1), pp. 58-81. DOI: 10.1501/SBFder_0000002154

Erkan, N. Ç. (2015) Büyük Kentlerde Kadınların Korku Mekanları. In Solak, A. \& Solak, Ö. (eds.) Gündelik Hayat Sosyolojisi Açısından Suç ve Suç Korkusu, pp. 401-411. Ankara, Hegem Yayınları.

Ferraro, K. F. (1995) Fear of crime: Interpreting victimization risk. Albany, State University of New York Press.

Ferraro, K. F. \& LaGrange, R. L. (1987) The measurement of fear of crime, Sociological Inquiry, 57(1), pp. 70-97. DOI:10.1111/j.1475-682x.1987.tb01181.x
Ferraro, K. F. \& LaGrange, R. L. (1992) Are older people most afraid of crime? Reconsidering age differences in fear of victimization. Journal of Gerontology, 47(5), pp. 233-244. DOI: 10.1093/geronj/47.5.s233

Foster, S., Giles-Corti, B. \& Knuiman, M. (2010) Neighbourhood design and fear of crime: A social-ecological examination of the correlates of residents? Fear in new suburban housing developments. Health \& Place, 16(6), pp. 1156-1165. DOI: 10.1016/j.healthplace.2010.07.007

Franklin, T. W., Franklin, C. A. \& Fearn, N. E. (2008) A multilevel analysis of the vulnerability, disorder, and social integration models of fear of crime. Social Justice Research, 21(2), pp. 204-227.

DOI: 10.1007/s11211-008-0069-9

Furstenberg, F. F., Jr. (1971) Public reaction to crime in the streets. The American Scholar, 40, pp. 601-610.

Garofalo, J. (1981) The fear of crime: Causes and consequences. The Journal of Criminal Law and Criminology, 72(2), pp. 839-857. DOI: $10.2307 / 1143018$

George, D. \& Mallery, M. (2010) SPSS for Windows step by step: A simple guide and reference, 17.0 update (10th ed.). Boston, Pearson.

Gilchrist, E., Bannister, J., Ditton, J. \& Farrall, S. (1998) Women and the "fear of crime": Challenging the accepted stereotype. The British Journal of Criminology, 38(2), pp. 283-298.

DOI: 10.1093/oxfordjournals.bjc.a014236

Gray, E., Jackson, J. \& Farrall, S. (2011) Feelings and functions in the fear of crime, applying a new approach to victimisation insecurity. British Journal of Criminology, 51, pp. 75-94. DOI: 10.1093/bjc/azq066

Greene, M. (2003) Urban safety in residential areas: Spatial variables in crime and feeling of (in)security. Paper presented at the World Bank Urban Research Symposium, 15-17 December, Washington, DC. Typescript.

Hale, C. (1993) Fear of crime: A review of the literature, report to the Metropolitan Police Service Working Party on the Fear of Crime. Research report. Canterbury, Canterbury Business School, University of Kent.

Internet 1: http://www.cumhuriyet.com.tr/haber/turkiye/607721/ Sort_giyen_kadina_tekme_atan_saldirganin_korkunc_sozleri_Kafasini_koparmak_lazim.html (accessed 3 Jun. 2021).

Internet 2: http://www.cumhuriyet.com.tr/haber/turkiye/765079/ Yine_sortlu_kadina_saldiri Ramazan_da_boyle_giyinmeye_utanmiyor_ musun_diyerek_yuzume_yumruk_atti.html (accessed 3 Jun. 2021).

Internet 3: https://listelist.com/kadikoyde-yasama-nedenleri/ (accessed 8 Jul. 2021).

Internet 4: https://www.indyturk.com (accessed 8 Jul. 2021).

Internet 5: http://www.gazetekadikoy.com.tr/gundem/kiyafetime-sortuma-hayatima-karisma-h10956.html (accessed 2 Oct. 2021).

Jackson, J. (2009) A psychological perspective on vulnerability in the fear of crime. Psychology, Crime \& Law, 15(4), pp. 365-390. DOI: 10.1080/10683160802275797

Kalpana, V. \& Ashish B. (2015) SafetiPin: An innovative mobile app to collect data on women's safety in Indian cities, Gender \& Development 23(1), pp. 45-60. DOI: 10.1080/13552074.2015.1013669

Karal, D. \& Aydemir, E. (2012) Türkiye'de Kadına Yönelik Șiddet, USAK Sosyal Araştırmalar Merkezi Raporu 12-01. Research report. Ankara, Uluslararası Stratejik Araştırmalar Kurumu.

Kohm, S. A., Waid-Lindberg, A., Weinrath, M., Shelley, T. O. C. \& Dobbs, R. R. (2012) The impact of media on fear of crime among university students: A cross-national comparison. Canadian Journal of Criminology and Criminal Justice 54, pp. 67-100. DOI: 10.3138/cjccj.2011.E.01 
Koskela, H. (1997) "Bold walk and breakings": Women's spatial confidence versus fear of violence. Gender, Place and Culture, 4, pp. 301-319. DOI: 10.1080/09663699725369

Koskela, H. (1999) "Gendered exclusions": Women's fear of violence and changing relations to space. Geografiska Annaler: Series B, Human Geography, 81(2), pp. 111-124. DOI: 10.1111/j.0435-3684.1999.00052.x

Kul, M. (2013) Suçtan Daha Büyük Suç Korkusu, İstanbul'da Bir Alan Araştırması. Istanbul, Yeniyüzyıl Yayınları.

Lordoğlu, C. (2018) İstanbul'da Bekar Kadın Olmak. Istanbul, illetişim Yayınları.

Macmillan, R., Nierobisz, A. \& Welsh, S. (2000) Experiencing the streets: Harassment and perceptions of safety among women. Journal of Research in Crime and Delinquency, 37, pp. 306-322.

DOI: $10.1177 / 0022427800037003003$

Mirrlees-Black, C, Mayhew, P. \& Percy, A. (1996) The 1996 British Crime Survey: England and Wales. London, Home Office.

Nasar, J. I. \& Fisher, B. (1993) "Hot spots" of fear and crime: A multi-method investigation. Journal of Environmental Psychology, 13, pp. 187-206. DOI: 10.1016/S0272-4944(05)80173-2

Newman, O. (1996) Creating defensible space. Washington, DC, Department of Housing and Urban Development, Office of Policy Development and Research.

Otis, M. D. (2007) Perceptions of victimization risk and fear of crime among lesbians and gay men. Journal of Interpersonal Violence, 22(2), pp. 198-217. DOI: $10.1177 / 0886260506295346$

Öztürk, M., Kocacık, F. \& Gönültaş, M. (2016) Suç korkusu ve risk algısının toplumsal cinsiyet açısından incelenmesi. Journal of Human Sciences, 13(1), pp. 1488-1502. DOI: 10.14687/ijhs.v13i1.3691

Pain, R. (1991) Space, sexual violence and social control: Integrating geographical and feminist analyses of women's fear of crime. Progress in Human Geography, 15, pp. 415-431. DOI: 10.1177/030913259101500403

Pain, R. (2001) Gender, race, age and fear in the city. Urban Studies, 38(5-6), pp. 899-913. DOI: 10.1080/00420980120046590

Pritschet, L., Powell, D. \& Horne, Z. (2016) Marginally significant effects as evidence for hypotheses: Changing attitudes over four decades. Psychological Science, 27(7), pp. 1036-1042. DOI: 10.1177/0956797616645672

Ravenscroft, N., Uzzell, D. \& Leach, R. (2002) Danger ahead? The impact of fear of crime on people's recreational use of nonmotorised shareduse routes. Environment and Planning C: Government and Policy, 20, pp. 741-756. DOI: $10.1068 / \mathrm{c} 24 \mathrm{~m}$

Ross, C. E. (1993) Fear of victimization and health. Journal of Quantitative Criminology, 9, pp. 159-175. DOI: 10.1007/BF01071166

Ross, C. E. \& Jang, S. J. (2000) Neighborhood disorder, fear, and mistrust: The buffering role of social ties with neighbors. American Journal of Community Psychology, 28, pp. 401-420. DOI: 10.1023/A:1005137713332

Sacco, V. F. (1993) Social support and the fear of crime. Canadian Journal of Criminology, 35, pp. 187-196. DOI: 10.3138/cjcrim.35.2.187

Sallan Gül, S. \& Altındal, Y. (2015) Kadın Cinayetlerinin ve Suç Korkusunun Görseller Üzerinden Medyada Yeniden Üretimi: Radikal Gazetesi Örneği. In: Solak, A. \& Solak, Ö. (eds.) Gündelik Hayat Sosyolojisi Açısından Suç ve Suç Korkusu, pp. 536-557. Ankara, Hegem Yayınları.

Sandberg, L. \& Rönnblom, M. (2013) Afraid and restricted vs bold and equal: Women's fear of violence and gender equality discourses in Sweden. European Journal of Women's Studies, 20(2), pp. 189-203. DOI: $10.1177 / 1350506812463911$
Smolej, M. \& Janne K. (2006) The relation between crime news and fear of violence. Journal of Scandinavian Studies in Criminology and Crime Prevention, 7(2), pp. 211-227. DOI: 10.1080/14043850601002429

Sutton, R. M., Robinson B. \& Farrall S. D. (2011) Gender, fear of crime, and self-presentation: An experimental investigation. Psychology, Crime \& Law, 17(5), pp. 421-433. DOI: 10.1080/10683160903292261

Tandoğan, O. \& Simsek Ilhan, B. (2016) Fear of crime in public spaces: From the view of women living in cities. Procedia Engineering, 161, pp. 2011-2018. DOI: 10.1016/j.proeng.2016.08.795

Taylor, R. B. \& Hale. M. (1986) Testing alternative models of fear of crime. Journal of Criminal Law and Criminology, 77, pp. 151-189. DOI: $10.2307 / 1143593$

Tığlı, N. (2019) Türkiye'de Kadın Cinayetleri Raporu, 01.01.2016-31.12.2018. Research report. Ankara, TBMM Kadın Erkek Fırsat Eşitliği Komisyonu Çalışması,

Treske, M., et al. (1990) Frauen Angst Rüume - ein Fotodokumentation. Frankfurt, AK Frauenraeume.

TÜiK (2016) İstatistiklerle Kadın Raporu. Research report. Ankara.

Uçan, A., et al. (2016) Türkiye'de Erkek Şiddetiyle Mücadele Mekanizmaları İleme Raporu. Research report. Istanbul, Mor Çatı Yayınları.

Uludağ, ş. (2010) Vatandaşların Suç Korku (Güvenlik Endişesi) Seviyesine Etki Eden Faktörler ve Alınabilecek Önlemler: Malatya Örneği. Polis Bilimleri Dergisi, 12(1), pp. 1-28.

Valentine, G. (1989) The geography of women's fear. Area, 21(4), pp. 385-390.

Valentine, G. (1992) Images of danger: Women's sources of information about the spatial distribution of male violence. Area, 24(1), pp. 22-29.

Vrij, A. \& Winkel, F. W. (1991) Characteristics of the built environment and fear of crime: A research note on interventions in unsafe locations. Deviant Behaviour, 12, pp. 203-215. DOI: 10.1080/01639625.1991.9967 873

Ward, R. A., LaGory, M. \& Sherman, S. R. (1990) Fear of crime among the elderly as person/environment interaction. The Sociological Quarterly, 27(3), pp. 327-341. DOI: 10.1111/j.1533-8525.1986.tb00264.x

Warr, M. (1984) Fear of victimization: Why are women and the elderly more afraid? Social Science Quarterly, 65(3), pp. 681-702.

Warr, M. (1990) Dangerous situations: Social context and fear of victimization. Social Forces, 68(3), pp. 891-907. DOI: 10.2307/2579359

Yirmibeşoğlu, F. \& Ergun, N. (2015) Fear of crime among women in the old city center of Istanbul. Current Urban Studies, 3(2), pp. 161-174. DOI: 10.4236/cus.2015.32014 